\title{
A systematic review of the prevalence of mental and neurocognitive disorders amongst older adults' populace in Egypt
}

\author{
Opeyemi Odejimi ${ }^{*^{*}}$ (D), George Tadros ${ }^{2}$ and Noha Sabry ${ }^{3}$
}

\begin{abstract}
Background: Mental and neurocognitive disorders are the leading cause of disabilities amongst the older adult populace worldwide. The population of the older adult in Egypt is fast growing. The national census in 2017 revealed a $2.56 \%$ increase in the older adult population from the 2006 census, and these figures are expected to double by year 2031. This study aims to review current evidence about the prevalence of mental and neurocognitive disorders amongst older adult population in Egypt.
\end{abstract}

Results: A systematic review was carried out, and 16 studies met the inclusion criteria outlined in this study. Four main mental and neurocognitive disorders were identified: depression, anxiety, cognitive impairment and dementia. The reported prevalence of depression, anxiety, dementia and cognitive impairment are 23.7-74.5\%, 14.2-72\%, $3.66-39.2 \%$ and $1.74-51.4 \%$, respectively. Anxiety and depression were positively correlated with the female gender, increasing age and lower educational status. Also, cognitive impairment and dementia were positively correlated with age, illiteracy or low education. However, there appears to be inconsistencies in the diagnostic tools used.

Conclusion: Egypt aging population is growing, and this research brings to forefront the scale of mental and neurocognitive disorders amongst the older adult population. This may help ensure evidence-based initiatives are put in place and priority is given to resource allocation for geriatric mental and neurocognitive disorders in Egypt. Systematic review registration: PROSPERO CRD42018114831

Keywords: Mental disorders, Cognitive impairment, Dementia, Older adults, Egypt, Prevalence, Sociodemographic factors, Systematic review, Neurocognitive disorders

\section{Background}

Globally, the older adult population is fast growing, and this is subsequently reflected in the prevalence of old age-related diseases [1, 2]. Mental and neurocognitive disorders are the leading causes of disabilities amongst older population worldwide [3-5]. For, instance, mental disorders such as depression have been estimated to affect more than 300 million individuals globally and it is the single largest contributor to global disability [5].

\footnotetext{
*Correspondence: ope.odejimi@nhs.net; opeyemi.odejimi@gmail.com

${ }^{1}$ Psychiatric Liaison Department, Birmingham and Solihull Mental Health

Foundation Trust, Birmingham, UK

Full list of author information is available at the end of the article
}

The impact of mental and neurocognitive disorders is multifaceted affecting the individual, family and relatives as well as the economy of such countries [6]. For instance, the estimated cost per person in a year dementia in lowincome countries is approximately $£ 686$ (\$868) and $£ 2456$ (\$3109) in lower-middle income countries like Egypt [7].

The population of the older adults in Egypt is fast growing. In Egypt, old age classification begins at age 60, which is the same as the age of retirement $[8,9]$. There are now proposals to change retirement age to 65 years by 2027 , and this perhaps may change the definition of old age in

\section{Springer Open}

(c) The Author(s). 2020 Open Access This article is licensed under a Creative Commons Attribution 4.0 International License, which permits use, sharing, adaptation, distribution and reproduction in any medium or format, as long as you give appropriate credit to the original author(s) and the source, provide a link to the Creative Commons licence, and indicate if changes were made. The images or other third party material in this article are included in the article's Creative Commons licence, unless indicated otherwise in a credit line to the material. If material is not included in the article's Creative Commons licence and your intended use is not permitted by statutory regulation or exceeds the permitted use, you will need to obtain permission directly from the copyright holder. To view a copy of this licence, visit http://creativecommons.org/licenses/by/4.0/. 
the future [10]. The national census in 2017 revealed a $2.56 \%$ increase from the 2006 census, and it is expected that the older adult population will double by year 2031, with a projected increase of $11.5 \%$ forecasted [11].

Internationally, research which focuses on examining trends of mental and neurocognitive disorders amongst older adults' group is limited. Furthermore, uncertainties exist about prevalence and correlates of mental and neurocognitive disorders amongst older adults especially in the Middle East region and Egypt in particular. Therefore, this study aims to review current evidence about the prevalence of mental and neurocognitive disorders amongst older adult population in Egypt. Furthermore, sociodemographic correlates of these conditions will be investigated.

\section{Research questions}

- What is the prevalence of mental and neurocognitive disorders amongst older adult populace in Egypt?

- What are the sociodemographic correlates of mental and neurocognitive disorders amongst older adult populace in Egypt?

- What are the current gaps in research about mental and neurocognitive disorders amongst older adult populace in Egypt?

\section{Methods}

This systematic review was developed according to the Preferred Reporting Items for Systematic Reviews and Meta-Analyses (PRISMA) 2009 checklist [12] and the documented in a protocol (PROSPERO registration number: CRD42018114831) [13].

\section{Search strategy}

Electronic search was conducted on November 1, 2018, on five key databases (MEDLINE, PsychINFO, EMBASE, AMED and PUBMED). All databases were searched from their date of inception. In addition, we carried out key journal searching, citation searching, reference list scanning and relevant internet resources to ensure this systematic review contains all possible studies and also ascertain that studies not indexed in the five databases listed above were included in this review.

Prior to commencing the literature search, the Centre for Reviews and Dissemination as well as PROSPERO was accessed to identify if there had been a previous or ongoing systematic review carried out in Egypt. We found one study by Elshahidi et al. [3] that had carried out a systematic review on the prevalence of dementia in Egypt. However, our study is focused around mental and neurocognitive disorders using the International
Classification of Disease (ICD) code 10, chapter 5 (F code) for mental and behavioural disorder, of which dementia is a type of neurocognitive disorders. Thus, our study covers a wider range of mental and neurocognitive disorders. Moreover, our inclusion and exclusion criteria are quite different from those recorded in the study by Elshahidi et al. [6].

An updated search was carried out on the 28th of December, 2018; no additional paper was found. Searches included MeSH and text word terms, with combination AND, OR, ADJ Boolean operator and truncation when necessary. The search terms used in this study is detailed in Fig. 1:

\section{Inclusion and exclusion criteria}

Studies were included in this review, if they were published in English, cross-sectional prevalence studies, and carried out on adult Egyptians aged 60 and above. In addition, mental and neurocognitive disorders had to be ascertained using any validated diagnostic tools. Validation of diagnostic tools is based on self-reported declaration of the original authors of included papers. We included studies conducted in hospitals (both inpatients and outpatients), residential homes, household surveys and other settings within Egypt. Studies which did not meet any of the criteria detailed above were excluded.

\section{Search outcome}

The literature search from the five databases revealed 343 papers; this was reduced to 296 after duplicates were removed. Of the 296 papers, 268 were excluded after screening the title and abstract resulting in 29 papers being retrieved for more details. We also carried out citation scanning, reference list scanning and internet source search and identified 9 more studies that were potentially relevant. Thus, a total of 38 full articles were accessed, and after matching it with the eligibility criteria, 16 studies were included in this study (see Appendix 1 for list of included studies). Figure 2 provides details of the search outcome. Papers were excluded due to age ( $<60$ years or unspecified) and unspecified diagnostic criteria and focusing more on chronic illnesses which co-morbid with mental and neurocognitive disorders. We identified two potentially relevant papers based on the title and abstract; however, both were later excluded when the full article could not be accessed.

\section{Quality assessment}

The 16 studies which met the inclusion criteria were assessed using the Herzog et al. [14] modification of the Newcastle-Ottawa scale adapted for cross-sectional studies (see Appendix 2 for a template). This scale 


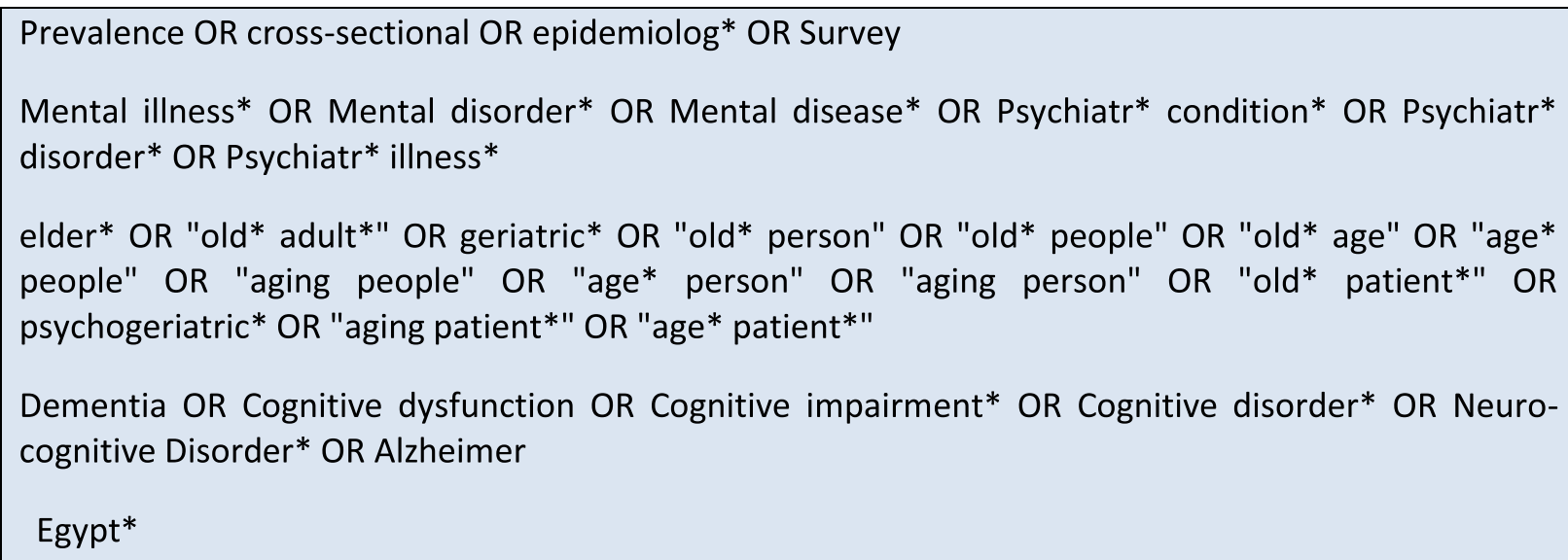

Fig. 1 Search terms

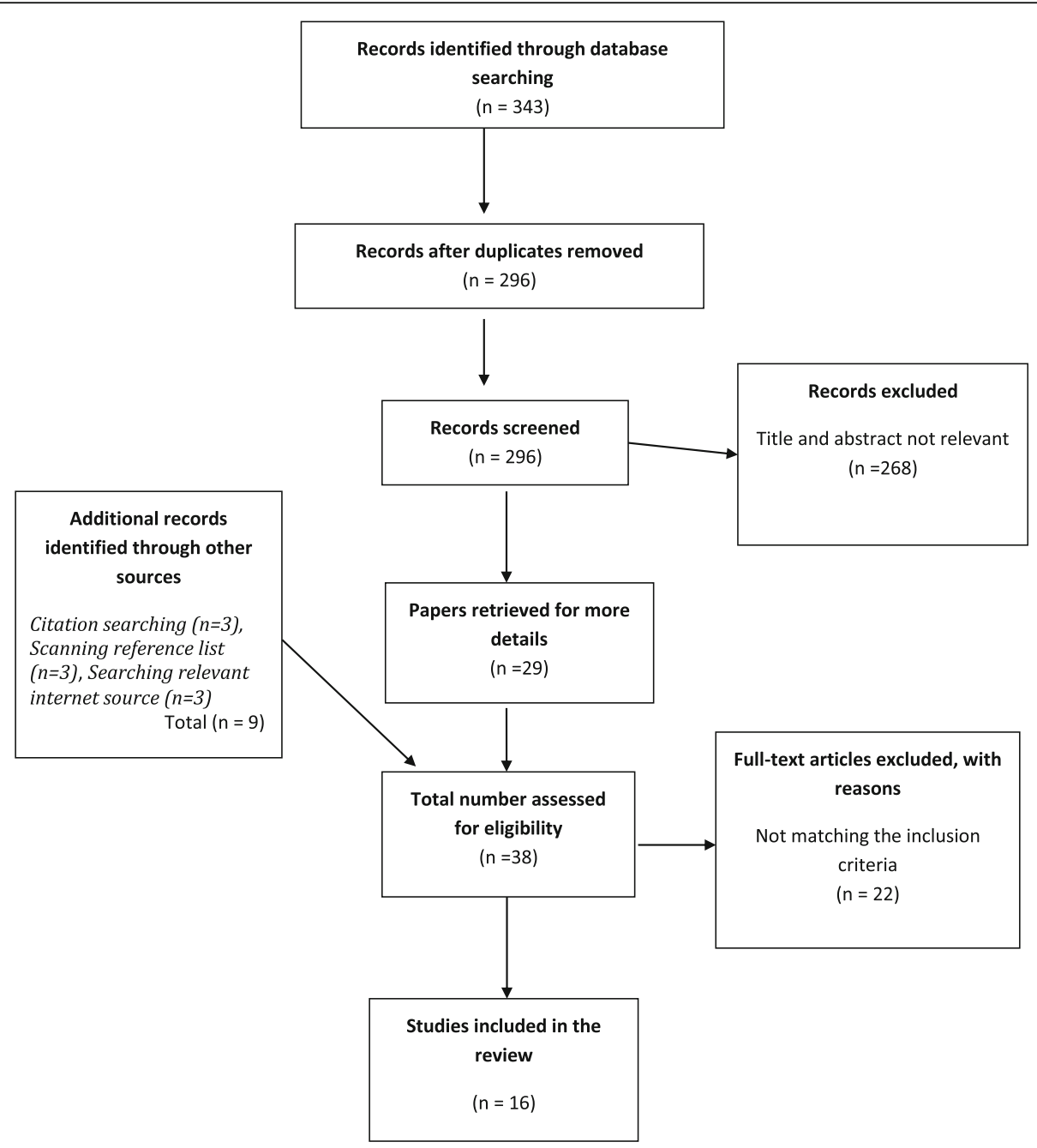

Fig. 2 PRISMA flow illustrating the search outcome 
assesses three main domains which are selection, comparability and outcomes. Each study could attain a maximum of 10 points.

In this study, we took out question 4 about exposure risk as it was not relevant to this systematic review. Thus, quality assessment was based on 8 points. We also modified the grading as we realised that using the old grading will wrongly categorise those studies. The new grade scale was $0-2$ point, unsatisfactory; $3-4$ point, satisfactory; 5-6 point, good; and 7-8 point, very good. See Appendix 2 for the quality assessment of included studies.

Two reviewers assessed the risk of bias, and disagreements were resolved by discussion. Ten of the studies were classed as good, and five were very good with only one classed as unsatisfactory.

\section{Data extraction}

Two reviewers performed data extraction, and any disagreements were resolved by discussion. The following information was extracted: first author's name; year of publication; city, settings and duration of the study; demographics; number of participants; method of recruitment; diagnostic test used; mental and neurocognitive disorder studied; prevalence of mental and neurocognitive disorders; existence of co-mobility, current medication and smoking status.

\section{Results}

\section{Demographic information}

All studies gathered demographic information such as age and gender. All but one study (study 10) (93.75\%) reported information about the educational status of the participants. Marital and employment status were reported by more than half of the papers $(56.25 \%)$, and less than half $(37.5 \%)$ examined the living arrangement of participants. Furthermore, less than half of the studies (43.75\%) indicated whether participants resided in urban or rural region. Table 1 contains the demographic details of all included studies.

\section{Sample and population}

The included studies were conducted in various cities in Egypt of which more than a quarter (37.5\%) were from Cairo (studies 1, 2, 4, 11, 14 and 15). The studies were conducted in five major settings: residential homes, community surveys, inpatients, outpatients and community clubs. Of the 16 studies, a quarter $(25 \%)$ was community surveys (studies $3,7,8$ and 10). One study (study 5) was a mix of three settings (residential homes, community surveys and inpatient). It was difficult to specify the settings where two studies (studies 11 and 13) were conducted. All studies were cross-sectional prevalence
Table 1 Demographic details of included studies

\begin{tabular}{|c|c|c|c|c|c|c|c|}
\hline Study no. & Age & Gender & MS* & $\mathrm{LA}^{*}$ & $\mathrm{ES}^{*}$ & EDUS* & Res* \\
\hline 1. & $x$ & $x$ & & & & $x$ & \\
\hline 2. & $x$ & $x$ & $x$ & & $x$ & $x$ & \\
\hline 3. & $x$ & $x$ & $x$ & & $x$ & $x$ & $x$ \\
\hline 4. & $x$ & $x$ & $x$ & & & $x$ & \\
\hline 5. & $x$ & $x$ & $x$ & $x$ & $x$ & $x$ & \\
\hline 6. & $x$ & $x$ & $x$ & $x$ & $x$ & $x$ & $x$ \\
\hline 7. & $x$ & $x$ & & & $x$ & $x$ & $x$ \\
\hline 8. & $x$ & $x$ & & & & $x$ & $x$ \\
\hline 9. & $x$ & $x$ & & & $x$ & $x$ & $x$ \\
\hline 10. & $x$ & $x$ & & & & & $x$ \\
\hline 11. & $x$ & $x$ & & & & $x$ & \\
\hline 12. & $x$ & $x$ & $x$ & $x$ & & $x$ & \\
\hline 13. & $x$ & $x$ & & & & $x$ & \\
\hline 14. & $x$ & $x$ & $x$ & $x$ & $x$ & $x$ & \\
\hline 15. & $x$ & $x$ & $x$ & $x$ & $x$ & $x$ & \\
\hline 16 & $x$ & $x$ & $x$ & $x$ & $x$ & $x$ & $x$ \\
\hline
\end{tabular}

$M S^{*}$ marital status, $L A^{*}$ living arrangement, $E I S^{*}$ employment and income status, EDUS* educational status, RES* resident in urban or rural region

studies, but two (studies 1 and 11) did not specify data collection period or duration.

Random sampling technique (56.25\%) was more commonly used amongst the included papers. All community surveys used this method and provided in-depth information of how randomisation occurred. Three studies (studies 2, 6 and 13) claiming to use this technique were vague in their explanation. For instance, one study (study 2) claimed to have randomly selected the study setting but did not randomly select the participants. Five studies (studies 1, 9, 11, 12 and 14) making 31.25\% did not specify the sampling technique, while two studies (studies 4 and 15) making 12\% used convenience sampling.

Sample size varied widely with some studies using a small number and others using a large number. The community surveys tend to use a larger sample size. More studies (56.25\%) provided details justifying their sample size. One study's (study 5) justification of sample size is unclear. The study made comparison between 3 settings (residential homes, inpatient wards and community survey in a slum area) and claimed 100 participants was the ideal sample size. Table 2 contains details about the sample and population of the included paper

\section{Mental and neurocognitive disorders}

This systematic review identified mental disorders, such as anxiety and depression, as well as neurocognitive disorders, such as cognitive impairment and dementia. Majority $(81.25 \%)$ of the studies were conducted solely to estimate the prevalence of these illnesses; however, three 
Table 2 Sample and population of included studies

\begin{tabular}{|c|c|c|c|c|c|}
\hline Study no. & City & $\begin{array}{l}\text { Data collection } \\
\text { settings }\end{array}$ & $\begin{array}{l}\text { Period of data } \\
\text { collection }\end{array}$ & $\begin{array}{l}\text { Sample } \\
\text { size }\end{array}$ & Method of recruitment \\
\hline 1 & Cairo & Residential homes & Unspecified & 120 & Unspecified \\
\hline 2 & Cairo & Residential homes & Jan 2014-Mar 2014 & 240 & $\begin{array}{l}\text { Randomly selected residential homes but } \\
\text { convenient for participants }\end{array}$ \\
\hline 3 & Fayoum & Community survey & Sept 2014-Feb 2015 & 2219 & Multistage stratified cluster random \\
\hline 4 & Cairo & Community clubs & 9 months starting Aug 2006 & 268 & Convenient \\
\hline 5 & Alexandria & A mix & Mar 2011-Aug 2011 & 100 & Random \\
\hline 6 & Zagazig & Inpatient & Apr 2012-Mar 2013 & 200 & Random, sample size not explained \\
\hline 7 & Assiut-upper & Community survey & May 1993-Aug 1994 & 2000 & Systematic random sampling \\
\hline 8 & Qena & Community survey & Sept 2011-Aug 2013 & 691 & Systematic random sampling \\
\hline 9 & Zagazig (Sharkia) & Outpatient & Jun 2004-May 2006 & 1800 & Unspecified \\
\hline 10 & Sohag & Community survey & May 2016-Mar 2017 & 1027 & Systematic random sampling \\
\hline 11 & Cairo & Unclear & Unspecified & 94 & Unspecified \\
\hline 12 & Assiut & Community clubs & 4 months starting Apr 2010 & 466 & Unspecified \\
\hline 13 & Mansoura & Community??? Unclear & Dec 2008-June 2009 & 100 & Random??unclear \\
\hline 14 & Cairo & Community clubs & ?? Over 3 months & 284 & Unspecified \\
\hline 15 & Cairo & Inpatient & May 2005-Oct 2005 & 100 & Convenience \\
\hline 16 & Damanhour & Outpatient & Nov 2009-Apr 2010 & 273 & Random \\
\hline
\end{tabular}

Mix* residential homes, household and inpatient

studies (studies 1, 3 and 11) (18.75\%) were conducted to estimate the association of these illnesses with other chronic health conditions. Two studies (studies 4 and 14) were aimed to validate Arabic version of diagnostic tools. For clarity, findings about mental disorders (depression and anxiety) will be presented first; then, neurocognitive disorders (cognitive impairment and dementia) will be discussed later.

\section{Mental disorders}

Eight of the 16 included studies reported the prevalence of mental disorders. Amongst these eight studies, two (studies 6 and 15) investigated the prevalence of both anxiety and/or depression with cognitive impairment. Hence, these studies are also reported in the cognitive impairment and dementia section later.

Table 3 illustrates the prevalence of mental disorders reported in this study. Reported prevalence of depression ranged from 23.7 to $74.5 \%$ and anxiety from 14.2 to $72 \%$, with mixed anxiety and depression disorder stated as $30 \%$ by one study (study 1 ). The manner two studies (studies 5 and 16) reported prevalence rate was cumbersome, and we will suggest that readers access these papers for further details. The prevalence of anxiety and depression reported varied with the data collection setting. It was noted that residential homes and community clubs had a lower prevalence compared with inpatient and household community survey.

Generally, depression was detected using the Geriatric Depression Scale (GDS). One study (study 16) detected depression from the participants by conducting psychiatric assessment using Structured Clinical Diagnosis (SCID-1) and arriving at a diagnosis based on the Diagnostic and Statistical Manual of Mental Disorders (DSM-IV). There was inconsistency in the GDS scale format used, more studies utilised the short form version, and only two studies (studies 3 and 15) used the long version. The GDS scale could sometimes be the Arabic version which had been previously validated or one simply translated to Arabic for the purpose of the study. The cutoff point for both the short and long versions of the GDS also varied amongst studies, with some using 5 or 6 points for the short and 10 or 11 for the long version, respectively. Anxiety was reported in three studies (studies 2, 15 and 16), and all three used different kinds of diagnostic tool.

Amongst the eight studies, all except one (study 15) indicated some type of correlation with sociodemographic status. See Table 4 for the relationship between depression and/or anxiety with sociodemographic status. It was mostly stated that depression and anxiety were positively correlated with the female gender. Furthermore, increasing age and lower 
Table 3 Prevalence of depression and anxiety

\begin{tabular}{|c|c|c|c|c|}
\hline $\begin{array}{l}\text { Study } \\
\text { no. }\end{array}$ & $\begin{array}{l}\text { Mental/neurocognitive } \\
\text { condition studied }\end{array}$ & $\begin{array}{l}\text { Data collection } \\
\text { settings }\end{array}$ & Prevalence rate & $\begin{array}{l}\text { Diagnostic tool } \\
(*, \text { Arabic version; } \wedge \text {, shorter version; !, longer } \\
\text { version; [ ], cut-off point; ", translated to Arabic) }\end{array}$ \\
\hline 2 & $\begin{array}{l}\text { Depression, } \\
\text { Anxiety } \\
\text { Mixed disorder }\end{array}$ & Residential homes & $\begin{array}{l}\text { Depression }=37.5 \% \\
\text { Anxiety }=14.2 \% \\
\text { Mixed disorder }=30 \%\end{array}$ & $\begin{array}{l}\operatorname{GDS} \wedge *[\geq 5] \\
(5-7=\text { mild; } 8-12=\text { moderate; } \geq 13=\text { severe } \\
\text { Hamilton anxiety }[\geq 18]\end{array}$ \\
\hline 3 & Depression & $\begin{array}{l}\text { Household } \\
\text { community } \\
\text { survey }\end{array}$ & $\begin{array}{l}\text { Depression }=74.5 \% \\
(\mathrm{Mild}=57.7 \% \text { and severe }=16.8 \%)\end{array}$ & $\begin{array}{l}\text { GDS! }[\geq 10] \\
(0-9=\text { normal; } 10-19=\text { mild; } 20-30=\text { severe })\end{array}$ \\
\hline 5 & Depression & A mix & See article & $\begin{array}{l}\mathrm{GDS} \wedge "[\geq 5] \\
(0-4=\text { no depression; } 5-9=\text { suggestive of } \\
\text { depression; }>9=\text { indicative of depression) }\end{array}$ \\
\hline 6 & $\begin{array}{l}\text { Depression } \\
\text { Cognitive impairment }\end{array}$ & Inpatient & $\begin{array}{l}\text { Depression }=72 \% \\
\text { Cognitive impairment }=30 \%\end{array}$ & $\begin{array}{l}\text { GDS }[\geq 6] \\
\text { MMSE }[\leq 23]\end{array}$ \\
\hline 10 & Depression & $\begin{array}{l}\text { Household } \\
\text { community } \\
\text { survey }\end{array}$ & $\begin{array}{l}\text { Depression }=62.7 \% \text { (mild, } 43.8 \% \text {; } \\
\text { moderate, } 18.9 \% \text { no severe dep) }\end{array}$ & $\begin{array}{l}\text { GDS-15^*}[\geq 5] \\
(<5=\text { normal; } 5-8=\text { mild; } 9-11=\text { moderate; } \\
12-15=\text { severe })\end{array}$ \\
\hline 12 & Depression & Community clubs & Depression $=23.3 \%$ & $\mathrm{GDS} \wedge[\geq 5]$ \\
\hline 15 & $\begin{array}{l}\text { Anxiety } \\
\text { Depression } \\
\text { Cognitive impairment }\end{array}$ & Inpatient & $\begin{array}{l}\text { Anxiety }=72 \% \\
\text { Anxiety traits }=35 \% \\
\text { Depression }=64 \% \\
\text { Cognitive impairment }=26 \%\end{array}$ & $\begin{array}{l}\text { STAl* } \\
\text { GDS!" }[\geq 11] \\
(11-20=\text { mild; } 21-30=\text { severe }) \\
\text { MMSE* }^{*}[\mathrm{Cl}=\leq 24]\end{array}$ \\
\hline 16 & Anxiety and depression & Outpatient & See article & $\begin{array}{l}\text { MMSE [23, educated participants; 20, illiterate] } \\
\text { and DSM-IV (SCID-I) }\end{array}$ \\
\hline
\end{tabular}

educational status was reported as positively correlated with depression and anxiety. With regards to marital status, one study (study 2) reported a positive correlation of anxiety with married elderly. Others indicated a positive relationship with those who are divorced, widowed or separated.

Four (studies 3, 6, 10 and 16) of the eight studies reported the residency status (urban or rural) of the study. All four studies reported more participants residing in rural than urban areas. Only one study (study 10) reported a significant increase in the prevalence of depression amongst the rural resident. Generally, it was indicated that both depression and anxiety was significantly associated with presence of co-morbid chronic diseases, poor perceived health status, having more than one chronic illness and loneliness.

\section{Neurocognitive disorder}

Table 5 presents the prevalence of dementia and cognitive impairment. In total, 10 studies reported findings, and this was a mix of cognitive impairment alone (studies 1, 4 and 13), dementia alone (studies 7 and 9), both cognitive impairment and dementia (studies 8, 11 and 14) and both anxiety and/or depression with cognitive impairment (studies 6 and 15).

Table 4 Reported significant positive correlation of depression and anxiety with sociodemographic status

\begin{tabular}{|c|c|c|c|c|c|c|c|}
\hline Study no. & Age & Gender & $\mathrm{MS}^{*}$ & $\mathrm{LA}^{*}$ & EIS* & EDUS* & Res* \\
\hline 2 & $\begin{array}{l}\uparrow \text { age with anxiety } \\
\text { and mixed disorder }\end{array}$ & Female & $\uparrow$ anxiety with married & & Low income & & \\
\hline 3 & Aged 70+ & Female & Divorced/widowed & & Lower education & Lower education & $\begin{array}{l}\text { Males in the } \\
\text { urban region }\end{array}$ \\
\hline 5 & & Female & Single/widowed & Living with offspring & Low income & Lower education & \\
\hline 6 & & & & & Low income & & \\
\hline 10 & Aged 90+ & Female & & & & & Rural \\
\hline 12 & Aged 60-65 & Female & Separated/divorced & Living alone & & Lower education & \\
\hline \multicolumn{8}{|l|}{15} \\
\hline 16 & & Female & Divorced & & Low income & & \\
\hline
\end{tabular}

$M S^{*}$ marital status, $L A^{*}$ living arrangement, EIS* employment and income status, EDUS* educational status, RES* resident in urban or rural region 
Table 5 Prevalence of cognitive impairment and dementia

\begin{tabular}{|c|c|c|c|c|}
\hline $\begin{array}{l}\text { Study } \\
\text { no. }\end{array}$ & $\begin{array}{l}\text { Mental/neurocognitive } \\
\text { condition studied }\end{array}$ & $\begin{array}{l}\text { Data } \\
\text { collection } \\
\text { settings }\end{array}$ & Prevalence rate & $\begin{array}{l}\text { Diagnostic test }\left(^{*}, \text { Arabic version; } \wedge \text {, shorter version; !, }\right. \\
\text { longer version; [ ], cut-off point; ", translated to Arabic) }\end{array}$ \\
\hline 1 & Cognitive impairment & $\begin{array}{l}\text { Residential } \\
\text { homes }\end{array}$ & $38.30 \%$ & MMSE*; MoCA* $[<26]$ bonus point given for less than 12 years education \\
\hline 4 & Cognitive impairment & $\begin{array}{l}\text { Community } \\
\text { clubs }\end{array}$ & $\begin{array}{l}34.2 \text { and } 44.3 \% \text { in healthy men } \\
\text { and women, respectively }\end{array}$ & $\begin{array}{l}\text { MOCA*, similar to English version, } \leq 26 \text { with no functional impairment }=\mathrm{MCl} ; \\
\leq 26 \text { with functional impairment }=\text { early dementia, bonus point given for less } \\
\text { than } 12 \text { years education }\end{array}$ \\
\hline 6 & $\begin{array}{l}\text { Cognitive impairment } \\
\text { Depression }\end{array}$ & Inpatient & $\begin{array}{l}\text { Cognitive impairment }=30 \% \\
\text { Depression }=72 \%\end{array}$ & $\begin{array}{l}\text { MMSE }[\leq 23] \\
\text { GDS }[\geq 6]\end{array}$ \\
\hline 7 & $\begin{array}{l}\text { Dementia (then further } \\
\text { classified as } A D^{*}, M D^{*}, M D^{*} \text {, } \\
\text { and Sec } D^{*} \text { ) }\end{array}$ & $\begin{array}{l}\text { Household } \\
\text { community } \\
\text { survey }\end{array}$ & $\begin{array}{l}\text { Dementia }=4.5 \% \\
\text { (AD 2.2\%, MID 0.95\%, MD } \\
0.55 \%, \operatorname{SeD} 0.45 \%)\end{array}$ & $\begin{array}{l}\text { MMSE of } 28 \text { points [ } \leq 21] \text { and other diagnostic tools for further classification } \\
\text { of dementia (see article) }\end{array}$ \\
\hline 8 & $\begin{array}{l}\text { Cognitive impairment } \\
\text { Dementia* } \\
\text { (then further classified as } \\
\mathrm{AD}^{*}, \mathrm{VaD}^{*}, \mathrm{PDD}^{*} \text {, and Mixed*) }\end{array}$ & $\begin{array}{l}\text { Household } \\
\text { community } \\
\text { survey }\end{array}$ & $\begin{array}{l}\text { Cognitive impairment }=1.74 \% \\
\text { Dementia }=5.07 \% \\
\text { (AD } 1.74 \%, \text { VaD } 1.3 \%, \text { PDD } \\
1.01 \%, \text { MD } 0.58 \%)\end{array}$ & $\begin{array}{l}\text { MMSE of } 28 \text { points [23 educated individuals and } 21 \text { illiterate) } \\
\text { - MES- Memory and Executive Screening test [ }>75 \text { normal; } 62-75 \mathrm{MCl} ;<62 \\
\text { dementia suspects] and other diagnostic tools for further classification of } \\
\text { dementia (see article) }\end{array}$ \\
\hline 9 & $\begin{array}{l}\text { Dementia } \\
\text { (then further classified as } \\
A D^{*}, M D^{*}, V a D^{*} \text {, others, and } \\
\text { undet*) }\end{array}$ & Outpatient & $\begin{array}{l}\text { Dementia }=3.66 \% \\
\text { (AD 1.4\%, VaD 1.05\%, MD 0.5\%, } \\
\text { Others 0.44\%, Undetermined } \\
0.22 \%)\end{array}$ & $\begin{array}{l}\text { Standardized MMSE of } 30 \text { points ( } 23 \text { educated individuals and } 21 \text { illiterate) } \\
\text { and other diagnostic tools for further classification of dementia (see article) }\end{array}$ \\
\hline 11 & $\begin{array}{l}\text { Cognitive impairment } \\
\text { Dementia }\end{array}$ & Unclear & $\begin{array}{l}\text { Cognitive impairment, } 34 \% \\
\text { Mild dementia, } 23.3 \% \\
\text { Moderate dementia, } 8.5 \% \\
\text { Severe dementia, } 7.4\end{array}$ & $\begin{array}{l}\text { MMSE of } 30 \text { points [0-10, severe; } 11-20 \text {, moderate; } 21-25 \text {, early dementia; } 29- \\
30, \mathrm{MCl}]\end{array}$ \\
\hline 13 & Cognitive impairment & $\begin{array}{l}\text { Community??? } \\
\text { Unclear }\end{array}$ & Cognitive impairment $=32 \%$ & $\begin{array}{l}\text { MMSE* (unspecified but stated that individuals below } 24 \text { were excluded) } \\
\text { MOCA* }[<26] \\
\text { Bonus point given for less than } 12 \text { years education }\end{array}$ \\
\hline 14 & $\begin{array}{l}\text { Cognitive impairment } \\
\text { Dementia }\end{array}$ & $\begin{array}{l}\text { Community } \\
\text { clubs }\end{array}$ & $\begin{array}{l}\text { Cognitive impairment }=51.4 \% \\
\text { Dementia }=5.6 \%\end{array}$ & $\begin{array}{l}\text { MMSE of } 30 \text { points } \\
\text { SLUMS*, score depends on level of education } \\
\text { For high education (normal = 27-30; mild neurocognitive disorder = 21-26; } \\
\text { dementia }=1-20 \text { ) } \\
\text { For less high school education (normal = 25-30; mild neurocognitive disorder } \\
=20-24 \text {, dementia }=1-19 \text { ) }\end{array}$ \\
\hline 15 & $\begin{array}{l}\text { Cognitive impairment } \\
\text { Depression } \\
\text { Anxiety }\end{array}$ & Inpatient & $\begin{array}{l}\text { Cognitive impairment }=26 \% \\
\text { Depression }=64 \% \\
\text { Anxiety }=72 \% \\
\text { Anxiety traits }=35 \%\end{array}$ & $\begin{array}{l}\mathrm{MMSE}^{*}[\mathrm{Cl}=\leq 24] \\
\mathrm{GDS}^{*} \\
\mathrm{STAl}^{*}\end{array}$ \\
\hline
\end{tabular}

$A D^{*}$ Alzheimer's disease, $V a D^{*}$ vascular dementia, $M D^{*}$ mixed dementia, $M I D^{*}$ multi-infarct dementia, $S e D^{*}$ secondary dementia, $P D D^{*}$ Parkinson's disease dementia

The reported prevalence of dementia was 3.66$39.2 \%$. All but one study (study 11) indicated a low prevalence rate of dementia. It is not particularly clear why the rate described in this study is particularly high (total dementia rate of $39.2 \%$ ); perhaps it could be due to the data collection settings unclear. It was stated that participants in this study were recruited from the hospital without indicating if they are outpatient or inpatient. Although, this particular study (study 11) did indicate they excluded individuals with possible health conditions that may affect cognitive function. However, the description of the sample population is unclear and this may impact on prevalence rate of dementia reported. There was a wide range in the reported prevalence of cognitive impairment from 1.74 to $51.4 \%$. Converse to findings about anxiety and depression, household community surveys reported a very low rate $(1.74 \%)$ compared to all other settings.
Three main types of diagnostic tools were reported in the included studies. Nearly all studies except one (study 4) used the Mini Mental State Examination (MMSE) to detect cognitive impairment and dementia. Three studies (studies 1,4 and 13) used the Montreal Cognitive Assessment (MoCA) to detect cognitive impairment, and one study (study 14) used Saint Louis University Mental Status (SLUMS). Different versions of the MMSE was used, the Arabic, standardised version of 30 points, or the 28 points versions were used. The three studies which used the MoCA scale all used the Arabic version. Amongst the five studies that investigated the prevalence of dementia, three (studies 7 , 8 and 9) used other diagnostic tools to further classify dementia into subtypes.

Table 6 presents studies which show significant positive correlation between cognitive impairment and/or dementia with sociodemographic status. All but one study (study 15) of the 10 studies did not 
Table 6 Reported significant positive correlation of cognitive impairment and dementia with sociodemographic status

\begin{tabular}{|c|c|c|c|c|c|c|c|}
\hline Study no. & Age & Gender & MS* & $L^{*}$ & $\mathrm{ES}^{*}$ & EDUS* & RES* \\
\hline 1 & $\mathrm{Age}^{\mathrm{c}}$ & Female $^{c}$ & & & & Illiterate $^{c}$ & \\
\hline 4 & $\mathrm{Age}^{\mathrm{c}}$ & Female $^{c}$ & & & & Low education ${ }^{c}$ & \\
\hline 6 & $\mathrm{Age}^{c}$ & & & & & & \\
\hline 7 & $A g e^{D}$ & & & & & & \\
\hline 8 & $\mathrm{Age}^{\mathrm{D}}$ & & & & & Illiterate $\mathrm{D}^{\mathrm{D}}$ & $\begin{array}{l}\text { Urban areas } \\
\text { Industrial areas }\end{array}$ \\
\hline 9 & $\mathrm{Age}^{\mathrm{D}}$ & & & & Manual worker ${ }^{D}$ & |lliterate $\mathrm{e}^{\mathrm{D}}$ & \\
\hline 11 & & & & & & Low education ${ }^{c}$ & \\
\hline 13 & $\mathrm{Age}^{c}$ & & & & & Low education ${ }^{c}$ & \\
\hline 14 & & & & & Unemployment ${ }^{\mathrm{D}}$ & Low education ${ }^{\mathrm{D}}$ & \\
\hline 15 & & & & & & & \\
\hline
\end{tabular}

$D$ dementia, $C$ cognitive impairment, $M S^{*}$ marital status, $L A^{*}$ living arrangement, EIS* employment and income status, EDUS* educational status, $R E S^{*}$ resident in urban or rural region

report any significant correlation between dementia and cognitive impairment with sociodemographic status, respectively.

Most of the studies indicated a positive correlation with age, illiteracy and low education with cognitive impairment and/or dementia. Two studies (studies 1 and 4) reported a positive correlation with female gender. Also, being unemployed and a manual worker was strongly associated with dementia. There was no report of a significant correlation between marital status and living arrangement. One study (studies 8) reported a positive relationship between living in urban and industrialised areas with dementia. Furthermore, three studies (studies 1, 13 and 14) stated a positive relationship between cognitive impairment and dementia with depression.

\section{Risk factors of mental and neurocognitive disorders}

Some studies reported some risk factors that can affect mental and neurocognitive disorders. Table 7 presents risk factors identified in this systematic review. Risk factors such as the use of medication, smoking and chronic health condition were discussed in the included studies. No study reported the alcohol status of the participants.

Only one study (study 5) (6.25\%) indicated if the sampled population were on medications or not at the time of data collection. This study indicated that there was a positive correlation between increased number of medications and depression. Less than half of the studies (31.25\%) stated the smoking status; however, there was no report of smoking having a positive association with anxiety, depression, cognitive impairments and dementia. Five studies (studies 4, 6 . 10, 11 and 14) did not report if the sample populations had co-existing chronic health condition. Just one study (study 9) reported a significant association between chronic health condition (hypertension) and dementia.

\section{Discussion}

This systematic review reports current evidence about mental and neurocognitive disorders amongst the older adult population in Egypt. Two mental disorders (anxiety and depression) and neurocognitive disorders (cognitive impairments and dementia) were identified in this review. To the best of our knowledge, this is the first systematic review that considers the prevalence of both mental and neurocognitive disorders amongst the older adult populace in Egypt. Moreover, this study investigates sociodemographic factors that could potentially influence these conditions.

It is interesting to note that no single study in this review investigated the wider range of mental disorders such as dissociative disorders, misidentification disorder, obsessive-compulsive disorder, posttraumatic stress disorder, late-onset psychosis and other psychotic features that may be found amongst the older adult population. The strong cultural and religious influence towards mental disorders in Egypt could be attributed to studies not reporting data on substance and alcohol misuse in order to avoid stigmatisation and discrimination [15, 16]. This opinion is supported by Ghanem et al.'s [17] study that examined mental disorders amongst individuals aged 18-64 years. These authors indicated that the low prevalence rate of alcohol and drug dependence reported may be inaccurate due to the fear of being ostracised by family members. 
Table 7 Reported risk factors

\begin{tabular}{|c|c|c|c|}
\hline Study no. & Use of medication & Smoking status & Chronic health condition \\
\hline 1. & & $\mathrm{x}$ & $\mathrm{x}$ \\
\hline 2. & & & $x$ \\
\hline 3. & & $x$ & $x$ \\
\hline 4. & & $x$ & \\
\hline 5. & $\mathrm{X}^{+}$ & & $\mathrm{x}$ \\
\hline \multicolumn{4}{|l|}{6.} \\
\hline 7. & & & $x$ \\
\hline 8. & & & $x$ \\
\hline 9. & & & $\mathrm{X}^{+}$ \\
\hline \multicolumn{4}{|l|}{10.} \\
\hline \multicolumn{4}{|l|}{11.} \\
\hline 12. & & & $x$ \\
\hline 13. & & $x$ & $x$ \\
\hline \multicolumn{4}{|l|}{14.} \\
\hline 15. & & $x$ & $x$ \\
\hline 16. & & & $x$ \\
\hline
\end{tabular}

$\overline{\mathbf{X}^{+}}$positive correlation

Depression and anxiety are classed as 'common mental disorders' whose prevalence continues to rise globally and known as the largest contributor to global disability (WHO, 2017). This study found higher rates of depression and anxiety in females, increasing age and lower educational status. These findings are homogenous in the Middle East North Africa (MENA) countries and also globally [5, 18, 19]. Eloul et al. [18] indicated that the higher depression rate amongst females in MENA countries can be attributed to postpartum depression and the altering roles of females in these countries.

The estimated prevalence of cognitive impairment and dementia in this study were higher than those reported in previous studies $[6,20]$. This may be attributed to this review looking at studies conducted in various settings. For instance, Elshahidi et al. [6] study only looked at studies conducted via household surveys. Besides, a higher prevalence of dementia is often noted in institutionalised settings in comparison with other settings [20]. As expected, dementia and cognitive impairment rose with increasing age and illiteracy. This is consistent with previous studies [1, $4,6,20,21]$.

The inconsistencies in the diagnostic tools may impact on the prevalence reported in some studies. This is because there might be variations in the way mental and neurocognitive disorders are defined and categorised [22]. Moreover, presence of risk factors such as smoking, alcohol, medication and co-existing chronic illnesses may also influence reported prevalence categorised [20-22].

\section{Conclusion}

Egypt's aging population is growing, and there is a need to prioritise research and interventions about mental and neurocognitive disorders amongst this population group. Egypt's strong cultural and religious influence also calls for public health interventions that educate and help to disabuse myths and misconceptions about mental and neurocognitive disorders. Recommendations for further research is for more studies that explore the wider range of mental disorders like psychosis, alcohol and drug dependence amongst the older adult population. Besides, prevalence studies that categorises cognitive impairment should be conducted. Also, studies should provide an extensive report of the influence of sociodemographic and other risk factors for mental and neurocognitive disorders.

The limitation of this study is that we might have excluded some potentially insightful studies because it did not meet the inclusion criteria. Nevertheless, this systematic review is unique as it contributes knowledge about the current evidence of the prevalence of mental and neurocognitive disorders amongst older adult population in Egypt. It also shed insights into sociodemographic correlates and possible risk factors of mental and neurocognitive disorders amongst the older adult population in Egypt. Moreover, a detailed description of the inclusion and exclusion criteria also will be valuable for other researchers who might want to explore mental and neurocognitive disorders in Egypt and other MENA countries. 


\section{Appendix 1}

Table $\mathbf{8}$ Studies included in the systematic review

\begin{tabular}{|c|c|}
\hline $\begin{array}{l}\text { Included } \\
\text { studies }\end{array}$ & References \\
\hline Study 1 & $\begin{array}{l}\text { Khater MS, Abouelezz NF. Nutritional status in older adults with mild cognitive impairment living in elderly homes in Cairo, Egypt. The journal of } \\
\text { nutrition, health \& aging. } 2011 \text { Feb 1;15(2):104-8. }\end{array}$ \\
\hline Study 2 & $\begin{array}{l}\text { Ahmed D, El Shair IH, Taher E, Zyada F. Prevalence and predictors of depression and anxiety among the elderly population living in geriatric homes in } \\
\text { Cairo, Egypt. The Journal of the Egyptian Public Health Association. } 2014 \text { Dec 1;89(3):127-35. }\end{array}$ \\
\hline Study 3 & $\begin{array}{l}\text { El-Sherbiny NA, Younis A, Masoud M. A comprehensive assessment of the physical, nutritional, and psychological health status of the elderly populace } \\
\text { in the Fayoum Governorate (Egypt). Archives of gerontology and geriatrics. } 2016 \text { Sep 1;66:119-26. }\end{array}$ \\
\hline Study 4 & $\begin{array}{l}\text { Rahman TT, El Gaafary MM. Montreal Cognitive Assessment Arabic version: reliability and validity prevalence of mild cognitive impairment among } \\
\text { elderly attending geriatric clubs in Cairo. Geriatrics \& gerontology international. } 2009 \text { Mar;9(1):54-61. }\end{array}$ \\
\hline Study 5 & $\begin{array}{l}\text { El Kady HM, Ibrahim HK. Depression among a group of elders in Alexandria, Egypt. EMHJ-Eastern Mediterranean Health Journal, 19 (2), 167-174, } 2013 . \\
2013 .\end{array}$ \\
\hline Study 6 & $\begin{array}{l}\text { Esmayel EM, Eldarawy MM, Hassan MM, Mahmoud AA, Mohamed SY. Mental health problems and sociodemographic correlates in elderly medical } \\
\text { inpatients in a university hospital in Egypt. Current gerontology and geriatrics research. 2013;2013. }\end{array}$ \\
\hline Study 7 & $\begin{array}{l}\text { Farrag AK, Farwiz HM, Khedr EH, Mahfouz RM, Omran SM. Prevalence of Alzheimer's disease and other dementing disorders: Assiut-Upper Egypt study. } \\
\text { Dementia and geriatric cognitive disorders. 1998;9(6):323-8. }\end{array}$ \\
\hline Study 8 & $\begin{array}{l}\text { Khedr E, Fawi G, Abbas MA, Mohammed TA, El-Fetoh NA, Al Attar G, Noaman M, Zaki AF. Prevalence of mild cognitive impairment and dementia among } \\
\text { the elderly population of Qena Governorate, Upper Egypt: a community-based study. Journal of Alzheimer's Disease. 2015 Jan 1;45(1):117-26. }\end{array}$ \\
\hline Study 9 & $\begin{array}{l}\text { Zaitoun A, Al Ma'moun A, Sarhan M, Selim A, Mousa G. Epidemiological study of dementia after retirement. Egypt J Neurol Psychiat Neurosurg. 2008;45: } \\
65-74 .\end{array}$ \\
\hline Study 10 & Aly HY, Hamed AF, Mohammed NA. Depression among the elderly population in Sohag governorate. Saudi medical journal. 2018 Feb;39(2):185. \\
\hline Study 11 & $\begin{array}{l}\text { Abdelrahman HM, Elawam AE, Alghitany AN. Cognitive impairment among Egyptian older adults on hemodialysis. Middle East Journal of Age and } \\
\text { Ageing. } 2014 \text { Jun;83(1195):1-7. }\end{array}$ \\
\hline Study 12 & Mohamed E, Abd-Elhamed M. Depression among elderly attending geriatric clubs in Assiut city, Egypt. J Am Sci. 2011;7:386-91. \\
\hline Study 13 & $\begin{array}{l}\text { Amer M, Mousa S, Khater M, Wahab WA. Prevalence of mild cognitive impairment among older adults living in Mansoura city, Egypt. Middle East } \\
\text { Current Psychiatry. } 2012 \text { Jan 1;19(1):3-7. }\end{array}$ \\
\hline Study 14 & $\begin{array}{l}\text { Abdelrahman HM, El Gaafary MM. Validation of arabic version of Saint-Louis-University-Mental-Status (SLUMS)-Examination and prevalence of cognitive } \\
\text { impairment in community dwelling Egyptian older adults. Middle East Journal of Age and Ageing. 2014 Oct;83(1492):1-9. }\end{array}$ \\
\hline Study 15 & $\begin{array}{l}\text { Hamza S, El Raashid AH, Kahla O. The impact of anxiety, depression and cognitive impairment on functioning in the physically ill elderly in Egypt. } \\
\text { Current Psychiatry. } 2006 \text { Jul;13(2):152-65. }\end{array}$ \\
\hline Study 16 & $\begin{array}{l}\text { Eissa AM, Hassan GA, Azam H, Sadek HA, El Awam I. Sociodemographic correlates of depression and anxiety disorders among physically ill elderly } \\
\text { patients. Middle East Current Psychiatry. } 2013 \text { Apr 1;20(2):73-9. }\end{array}$ \\
\hline
\end{tabular}

\section{Appendix 2}

\section{Newcastle-Ottawa Scale adapted for cross-sectional studies}

Cross-sectional Studies:

Very Good Studies: 9-10 points

Good Studies: $7-8$ points

Satisfactory Studies: $5-6$ points

Unsatisfactory Studies: 0 to 4 points

This scale has been adapted from the NewcastleOttawa Quality Assessment Scale for cohort studies to provide quality assessment of cross sectional studies ${ }^{1}$.

\section{Selection:}

\section{Representativeness of the sample:}

a. Truly representative of the average in the target population. " (all subjects or random sampling)

b. Somewhat representative of the average in the target group. " (non-random sampling)

c. Selected group of users/convenience sample. d. No description of the derivation of the included subjects.

\section{Sample size:}

a. Justified and satisfactory (including sample size calculation). *

b. Not justified.

c. No information provided

\section{Non-respondents:}

a. Proportion of target sample recruited attains pre-specified target or basic summary of nonrespondent characteristics in sampling frame recorded. *

b. Unsatisfactory recruitment rate, no summary data on non-respondents.

c. No information provided.

4. Ascertainment of the exposure (risk factor):

a. Vaccine records/vaccine registry/clinic registers/ hospital records only. ${ }^{* * *}$

b. Parental or personal recall and vaccine/hospital records. *

c. Parental/personal recall only. 
Comparability: (Maximum 2 stars)

\section{Comparability of subjects in different outcome groups on the basis of design or analysis. Confounding factors controlled.}

a. Data/results adjusted for relevant predictors/risk factors/confounders, e.g. age, sex, time since vaccination, etc. ${ }^{* * *}$

b. Data/results not adjusted for all relevant confounders/risk factors/information not provided.

\section{Outcome:}

\section{Assessment of outcome:}

a. Independent blind assessment using objective validated laboratory methods. $* *$

b. Unblinded assessment using objective validated laboratory methods. **

c. Used non-standard or non-validated laboratory methods with gold standard. "

d. No description/non-standard laboratory methods used.

\section{Statistical test:}

a. Statistical test used to analyse the data clearly described, appropriate and measures of association presented including confidence intervals and probability level ( $p$ value). *

b. Statistical test not appropriate, not described or incomplete.

\section{Appendix 3}

Table 9 Quality assessment of included studies

\begin{tabular}{lll}
\hline Studies & Points & Grading \\
\hline Studies 1 & 6 & Good \\
Studies 2 & 6 & Good \\
Studies 3 & 8 & Very good \\
Studies 4 & 5 & Good \\
Studies 5 & 5 & Good \\
Studies 6 & 5 & Good \\
Studies 7 & 8 & Very good \\
Studies 8 & 8 & Very good \\
Studies 9 & 7 & Very good \\
Studies 10 & 8 & Very good \\
Studies 11 & 5 & Good \\
Studies 12 & 6 & Good \\
Studies 13 & 6 & Good \\
Studies 14 & 5 & Good \\
Studies 15 & 3 & Satisfactory \\
Studies 16 & 6 & Good \\
\hline
\end{tabular}

\section{Grading scales}

$0-2=$ Unsatisfactory

3-4 =Satisfactory

$5-6=$ Good

$7-8=$ Very good

\section{Abbreviations}

WHO: World Health Organisation; PRISMA: Preferred Reporting Items for Systematic Reviews and Meta-Analyses; ICD: International Classification of Disease; GDS: Geriatric Depression Scale; SCID: Structured Clinical Diagnosis; DSM: Diagnostic and Statistical Manual of Mental Disorders; MS*: Marital status; LA*: Living arrangement; ElS*: Employment and income status; EDUS*: Educational status; RES*: Resident in urban or rural region; MMSE: Mini-Mental State Examination; MoCA: Montreal Cognitive Assessment; $A D^{*}$ : Alzheimer's disease; VaD*: Vascular dementia; $\mathrm{MD}^{*}$ : Mixed dementia; MID*: Multi-infarct dementia; SeD*: Secondary dementia; PDD*: Parkinson's disease dementia; D: Dementia; C: Cognitive impairment; MENA: Middle East North Africa

\section{Acknowledgements}

None.

\section{Authors' contributions}

OO was responsible for writing the protocol. OO and GT were involved in the conceptualisation of the study. OO and GT designed the search strategy. OO was responsible for the literature search. OO, GT and NS were responsible for the study selection, data extraction and quality assurance. All authors read and approved the final manuscript.

\section{Funding}

The authors received no funding for this work.

\section{Availability of data and materials}

All data generated or analysed during this study are included in this published article (and its supplementary information files).

Ethics approval and consent to participate

Not applicable.

Consent for publication

Not applicable.

\section{Competing interests}

The authors declare that they have no competing interest.

\section{Author details}

${ }^{1}$ Psychiatric Liaison Department, Birmingham and Solihull Mental Health Foundation Trust, Birmingham, UK. ${ }^{2}$ Aston Medical School, Aston University, Birmingham, UK. ${ }^{3}$ Cairo University, Cairo, Egypt.

Received: 6 July 2020 Accepted: 8 September 2020

Published online: 17 November 2020

References

1. Farrag AKF, Farwiz HM, Khedr EH, Mahfouz RM, Omran SM (1998) Prevalence of Alzheimer's disease and other dementing disorders: AssiutUpper Egypt study. Dementia and geriatric cognitive disorders, 9(6), 323328.

2. El Tallawy HN, Farghly WM, Badry R, Rageh TA, Shehata GA (2014) Prevalence of dementia in Al-Quseir city, Red Sea Governorate, Egypt. Clin Interv Aging 9:9

3. El Tallawy HN, Farghly WM, Shehata GA, Rageh TA, Hakeem NA, Abo-Elfetoh N et al (2012) Prevalence of dementia in Al Kharga District, New Valley Governorate, Egypt. Neuroepidemiology 38(3):130-137

4. Tallawy HNE, Farghaly WM, Abd El Hamed M, Badry R, Usama K, Shehata GA, Tohamy AM, Abdulghani KO, Ghanem MK, Sayed MA Yousef AH (2019) Prevalence of Alzheimer dementia in Upper Egypt (desert areas). The Egyptian Journal of Neurology, Psychiatry and Neurosurgery, 55(29). pp 1-6.

5. World Health Organization. (2017). Depression and other common mental disorders: global health estimates (No. WHO/MSD/MER/2017.2). World Health Organization.

6. Elshahidi MH, Elhadidi MA, Sharaqi AA, Mostafa A, Elzhery MA (2017) Prevalence of dementia in Egypt: a systematic review. Neuropsychiatr Dis Treat 13:715

7. World Health Organization. (2015). First WHO ministerial conference on global action against dementia: meeting report, WHO Headquarters, Geneva, Switzerland, 16-17 March 2015. 
8. Ahmed D, El Shair IH, Taher E, Zyada F (2014) Prevalence and predictors of depression and anxiety amongst the elderly population living in geriatric homes in Cairo, Egypt. The Journal of the Egyptian Public Health Association 89(3):127-135

9. Mostafa MHAT (2013) The old people in Egypt, case study (Ismailia Governorate). Central Agency for Public Mobilization and Statistics. Cairo, Egypt

10. Pension and Development Network. Egypt (2019). Pension and Development Network. Accessed 10 ${ }^{\text {th }}$, August 2019. Available at: http:// www.pensiondevelopment.org/393/egypt.htm

11. Central Agency for Public Mobilization And Statistics (2019). Current population. Central Agency for Public Mobilization and Statistics. Accessed $11^{\text {th }}$ September, 2019. Available at: https://www.capmas.gov.eg/HomePage. aspx

12. Moher D, Liberati A, Tetzlaff J, Altman DG, Prisma Group (2009) Preferred reporting items for systematic reviews and meta-analyses: the PRISMA statement. PLoS Med 6(7):e1000097

13. Odejimi O., Tadros, G, and Sabry, N (2018) A systematic review of the prevalence of mental disorders, cognitive impairment and dementia of the elderly populace in Egypt. PROPERO 2018. CRD4201811483. Available at: https://www.crd.york.ac.uk/PROSPERO/export_details_pdf.php

14. Herzog R, Álvarez-Pasquin MJ, Díaz C, Del Barrio JL, Estrada JM, Gil Á (2013) Are healthcare workers' intentions to vaccinate related to their knowledge, beliefs and attitudes? A systematic review. BMC Public Health 13(1):154

15. Endrawes G, O'Brien L, Wilkes L (2007) Mental illness and Egyptian families. Int J Ment Health Nurs 16(3):178-187

16. Odejimi O, Tadros G, Sabry N (2020) Prevalence of Mental Disorders, Cognitive Impairment, and Dementia Among Older Adults in Egypt: Protocol for a Systematic Review JMIR Res Protoc. 9(7):e14637. pp 1-6. http://www.researchprotocols.org/2020/7/e14637/; https://doi.org/10.2196/ 14637.

17. Ghanem, M., Gadallah, M., Meky, F. A., Mourad, S., \& El Kholy, G. (2009). National survey of prevalence of mental disorders in Egypt: preliminary survey. EMHJ-Eastern Mediterranean Health Journal, 15 (1), 65-75, 2009.

18. Eloul L, Ambusaidi A, Al-Adawi S (2009) Silent epidemic of depression in women in the Middle East and North Africa region: emerging tribulation or fallacy? Sultan Qaboos Univ Med J 9(1):5

19. Steel Z, Marnane C, Iranpour C, Chey T, Jackson JW, Patel V, Silove D (2014) The global prevalence of common mental disorders: a systematic review and meta-analysis 1980-2013. Int J Epidemiol 43(2):476-493

20. Petersen, R. C. (2016). Mild cognitive impairment. CONTINUUM: Lifelong Learning in Neurology, 22(2 Dementia), 404.

21. Fiest KM, Jette N, Roberts Jl, Maxwell CJ, Smith EE, Black SE et al (2016) The prevalence and incidence of dementia: a systematic review and metaanalysis. Can J Neurol Sci 43(S1):S3-S50

22. Hänninen T, Hallikainen M, Tuomainen S, Vanhanen M, Soininen H (2002) Prevalence of mild cognitive impairment: a population-based study in elderly subjects. Acta Neurol Scand 106(3):148-154

\section{Publisher's Note}

Springer Nature remains neutral with regard to jurisdictional claims in published maps and institutional affiliations.

\section{Submit your manuscript to a SpringerOpen ${ }^{\circ}$ journal and benefit from:}

- Convenient online submission

- Rigorous peer review

- Open access: articles freely available online

- High visibility within the field

- Retaining the copyright to your article

Submit your next manuscript at $\boldsymbol{\nabla}$ springeropen.com 